\title{
Effectiveness of the use of social competence formation model in preschool children with intellectual disabilities
}

\section{Anna Kurienkova, Yuliia Bondarenko}

\begin{abstract}
The article analyzes the state of the issue of social competence of preschool children with intellectual disabilities. The baseline data of social competence components levels are given by means of the diagnostic methodology developed by the author. The author's model of social competence formation of preschool children with intellectual disabilities is described. A comparative analysis of changes in the levels of social competence at the molding stage of the study in the control and experimental groups is conducted. The results obtained in practice testify to the effectiveness of using the author's model in the experimental group at the molding stage of the study.
\end{abstract}

Key words: model of social competence formation, preschoolers with intellectual disabilities, components of social competence. 


\title{
Efektivita využívání modelu formování sociální kompetence u předškolních dětí s mentálním postižením
}

\begin{abstract}
Abstrakt
Článek analyzuje stav problematiky sociálních kompetencí předškolních dětí s mentálním postižením. Základní údaje o úrovních složek sociálních kompetencí jsou uvedeny pomocí diagnostické metodiky vyvinuté autorkami a je popsán autorský model utváření sociálních kompetencí předškolních dětí s mentálním postižením. Byla provedena srovnávací analýza změn úrovní sociální způsobilosti ve fázi formování studie v kontrolních a experimentálních skupinách. Výsledky získané v praxi svědčí o účinnosti použití tohoto modelu v experimentální skupině ve fázi formování studie.
\end{abstract}

Klíčová slova: model tvorby sociálních kompetencí, předškoláků s mentálním postižením, složky sociálních kompetencí.

DOI: $10.5507 /$ epd.2020.009

\section{Introduction}

In the modern system of education in Ukraine, social development and formation of the personality of a preschooler with impaired intellectual development in the traditions of basic values of the universal culture are of particular importance. The main components of such development are socialization and individualization. Socialization acts as a process of involving a child in the social environment, and individualization - as a process of formation of universal social abilities that characterize degree of his/her independence. Socialization of a child is impossible without formation of social competence, under which scientists (O. Havrilushkina, A. Mudryk, et al.) understand the system of knowledge about social reality and about themselves, the system of complex social and interaction skills, scenarios of behavior in typical social situations.

Social competence of a person is formed throughout life, but the main ways of interaction and behavior in standard situations are laid in childhood. L. Vygotsky, A. Vysotska, D. Elkonin, V. Syniov and others consider this age as a sensitive period of human social development.

In the conditions of current changes in the educational system of Ukraine, the issue of social competence formation of children with intellectual disabilities arises extremely acute in the context of solving the problem of their integration into society. 
Many philosophical, psychological and pedagogical studies are devoted to investigation of the issue of social competence, among which we consider it necessary to note the works of M. Doktorovych, O. Kononko, L. Petrovska and others.

In the context of preschool education, social competence was considered by L. Bozhovych, O. Zaporozhets, O. Kononko, T. Ponymanska and others.

In Ukrainian special education, the issue of social competence formation is not elaborated enough. Formation and development of social competence in children of different nosologies were discussed in the studies of V. Bondar, K. Ostrovska, O. Pozdniakova, V. Syniov and others. Social activity, as a component of social competence, was considered by L. Nafikova, O. Telna and others.

However, we have not found any studies that examine the effectiveness of the ways of social competence formation of preschool children with intellectual disabilities. That is why the aim of our work was to determine the effectiveness of the use of the model of social competence formation of preschool children with intellectual disabilities.

\section{Analysis of the state of the issue of social competence of preschool children with intellectual disabilities}

Mastering of social experience and culture is a natural necessity. Society exists due to the transfer of historical experience to new generations, that is, it requires a certain level of social development.

Social development of a person is a quantitative and qualitative change of personality structures in the process of personality formation as a result of his/her socialization and education. This process is a natural phenomenon, characteristic of a person who has been in a social environment since birth. The environment of the child is one of the main engines of social development, without which personality cannot be formed.

According to L. Trubaichuk, social competence of a child of preschool age is determined by experience of surrounding reality cognition and acquisition of cultural values, behavior in the environment of peers and adults, is reflected in the ability to navigate in the situation that has arisen, awareness of the essence of what is happening, manifestation of emotional sensitivity to the state of surrounding people.

L. Trubaichuk in her works notes that the basis of social competence are basic competences acquired by the child and necessary for the entry of a growing personality into society. We believe that, taking into account psychological-pedagogical characteristics of children with intellectual disabilities, it is more appropriate to use the term "initial social competences" instead of the term "basic/key social competences", which will emphasize that the study deals with children of a particular nosology. We understand initial social competences as various manifestations of a child's awareness in matters 
of organizing interaction with children and adults, communicating with conventional means in accordance with accepted socio-cultural norms and rules.

Based on the research of H. Bilytska, O. Nikolaieva, N. Sodomnova and others, we believe that it is expedient to elucidate the concept of "social competence" in relation to children with intellectual disabilities. In our view, social competence of children with intellectual disabilities is comprised by initial competences (knowledge and skills) and social qualities that children with intellectual disabilities need to successfully interact in typical social situations, taking into account the values and traditions of the human culture of a particular society.

\section{Diagnostics of social competence formation levels of preschool children with intellectual disabilities}

The process of social competence formation in children with intellectual disabilities should start from the preschool age and continue throughout their education. Because of this, preschool age is one of the leading stages in acquiring basic social knowledge, skills and qualities by children.

Based on the components of social competence of children with intellectual disabilities, we have developed a four-block diagnostic methodology for identifying the levels of social competence components formation:

- I block- "social-motivational", which reflects the level of interest of preschoolers with impaired intelligence in the activity;

- Il block - "social-cognitive", which reflects the levels of necessary social knowledge (knowledge about oneself, about one's family and gender, about emotions and holidays);

- III block - "social-activity", which highlights social skills of children with intellectual disabilities (development of sanitary and hygienic skills, ability to perform social roles, behaviors in public places);

- IV block - "social-personality", reveals the levels of formation of qualities necessary for the formation of social competence (verbal communication, independence, activity, interaction with others, regulation of behavior).

This diagnostic methodology was implemented in:

- CE Sumy Special Rehabilitation Educational Complex: "Secondary School of the I Stage - Preschool Education Institution № 34", Sumy;

- Communal organization (institution, establishment) "Shostka preschool education institution (nursery school) № 9 "Desnianochka" of Shostka city council of Sumy region of Shostka; 
- Poltava preschool education institution (nursery school) of combined type № 41 "Hnizdechko", Poltava;

- CE "Pryluky Educational and Rehabilitation Center" of Chernihiv Regional State Administration of Pryluky.

The study involved 102 pupils of the above mentioned institutions aged 5-7 years old, 70 boys and 32 girls. During the ascertaining stage of the study, they were divided into control and experimental groups of 51 children each.

The study of social competence components of children with intellectual disabilities was carried out in the course of individual work, taking into account psychological and pedagogical features and secondary deviations of children. Application of the diagnostic methodology developed by the author gave us the following results at the ascertaining stage of the study in the control and future experimental groups (Table 1).

\section{Table 1}

Results of social competence components levels in control and experimental groups at the ascertaining stage of the study

\begin{tabular}{|c|c|c|c|c|c|c|c|c|}
\hline \multirow{2}{*}{ Levels } & \multicolumn{4}{|c|}{ Control group } & \multicolumn{4}{c|}{ Experimental group } \\
\cline { 2 - 10 } & I & II & \multicolumn{1}{|c|}{ III } & IV & I & II & III & IV \\
\hline Initial & $19,61 \%$ & $41,18 \%$ & $45,75 \%$ & $25,10 \%$ & $37,25 \%$ & $54,90 \%$ & $57,52 \%$ & $38,04 \%$ \\
\hline Medium & $52,94 \%$ & $45,49 \%$ & $45,75 \%$ & $54,12 \%$ & $47,06 \%$ & $37,25 \%$ & $37,91 \%$ & $49,02 \%$ \\
\hline Sufficient & $27,45 \%$ & $13,33 \%$ & $8,50 \%$ & $20,00 \%$ & $15,69 \%$ & $7,84 \%$ & $4,58 \%$ & $12,16 \%$ \\
\hline High & $0,00 \%$ & $0,00 \%$ & $0,00 \%$ & $0,78 \%$ & $0,00 \%$ & $0,00 \%$ & $0,00 \%$ & $0,78 \%$ \\
\hline
\end{tabular}

According to the obtained baseline data, we can state that children in general were not sufficiently motivated for activity, their level of socially important knowledge, skills, and qualities was insufficient, but in the first two institutions these indicators were lower, which testifies to the lack of efficiency of educational-upbringing and correctionaldevelopmental processes in preschool education institutions for children with intellectual disabilities. 


\section{Model of social competence formation of preschool children with intellectual disabilities}

Based on the obtained data, we have developed a methodology for using social roleplaying games, which should form components of social competence in preschoolers with intellectual disabilities.

It should be noted that, taking into account peculiarities of mental development of children with intellectual disabilities, it is necessary to create a targeted model of their social competence formation, on which this methodology will be based.

The following components were formed as a basis for our model of social competence formation of senior preschool children with intellectual disabilities:

- mastering of culture inherent in a given society, social community, group (rules, norms and patterns of behavior);

- mastering of social roles, communication skills, self-expression in the environment;

- accumulation of social behavior experience.

In order to improve the process of social competence formation in institutions of special preschool education, we have created a pedagogical model of social competence formation. This model consisted of four units: target, theoretical-methodological, contentactivity and diagnostic-resultative.

The first unit was target, which reflected the aim and tasks defined by us, conditioned by the requirements of Ukrainian society, which were put to upbringing of younger generation in the conditions of inclusion and integration. Therefore, our aim was to increase the level of social competence development in senior preschoolers with intellectual disabilities, on the basis of which we defined three tasks: increasing levels of interest in social activities; increasing levels of social knowledge and skills; increasing levels of social qualities of the individual.

The theoretical-methodological unit of the model highlights activity, competence, personality and integrative approaches that underlie this model. In addition to the approaches, important principles of general and special didactics, in our opinion, were selected.

The content-activity unit reveals pedagogical conditions, forms, methods and means of forming social competence in preschoolers with intellectual disabilities, which allow to simulate social situations in the form of play, to direct educational-upbringing and correctional-developmental processes.

In order to test and conduct qualitative-quantitative analysis of social competence formation and development of senior preschool children with intellectual disabilities, we have used a diagnostic-resultative unit. This unit highlights components of social competence, criteria that correspond to each component, and the level of social competence of preschoolers with intellectual disabilities. 
Fig. 1

Model of social competence formation of preschool children with intellectual disabilities

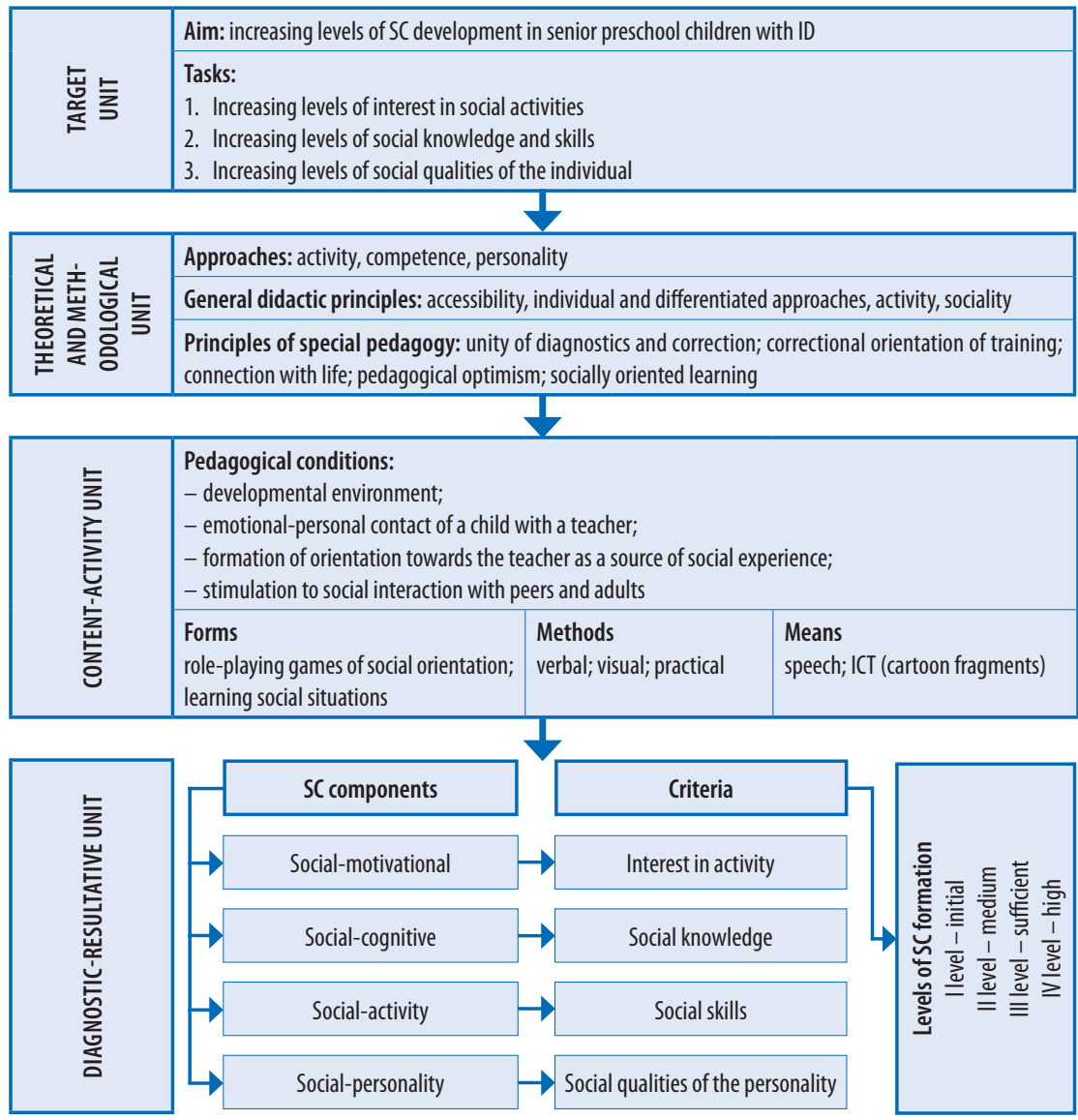

Result: increased levels of social competence development 
In addition to the units, the result of its implementation ispresented in the model: increased levels of social competence development.

The described model was implemented in the work of the first two institutions, from chosen by us, and their pupils were identified as an experimental group of the molding stage of the study. It should be noted that to the experimental group of the molding stage of the study we had selected children who had mostly initial level. With these children we used a large number of social role-playing games, and all educationalupbringing and correctional-developmental work was directed towards formation and development of their social competence components. Other children - participants of the control group - were enrolled in a standard educational program.

At the end of the molding stage of the experiment, we again diagnosed social competence components in the control and experimental groups and obtained the following results, which are shown in Table 2.

\section{Table 2}

Results of social competence components levels in the control and experimental groups at the molding stage of the study

\begin{tabular}{|c|c|c|c|c|c|c|c|c|}
\hline \multirow{2}{*}{ Levels } & \multicolumn{4}{|c|}{ Control group } & \multicolumn{4}{c|}{ Experimental group } \\
\cline { 2 - 10 } & I & II & III & IV & I & II & III & IV \\
\hline Initial & $27,45 \%$ & $49,02 \%$ & $51,63 \%$ & $28,24 \%$ & $9,80 \%$ & $23,14 \%$ & $31,37 \%$ & $17,65 \%$ \\
\hline Medium & $52,94 \%$ & $41,96 \%$ & $41,83 \%$ & $54,51 \%$ & $56,86 \%$ & $57,25 \%$ & $55,56 \%$ & $49,80 \%$ \\
\hline Sufficient & $19,61 \%$ & $9,02 \%$ & $6,54 \%$ & $16,47 \%$ & $33,33 \%$ & $19,61 \%$ & $13,07 \%$ & $28,63 \%$ \\
\hline High & $0,00 \%$ & $0,00 \%$ & $0,00 \%$ & $0,78 \%$ & $0,00 \%$ & $0,00 \%$ & $0,00 \%$ & $3,92 \%$ \\
\hline
\end{tabular}

\section{Comparative analysis of social competence formation in control and experimental groups at the molding stage of the study}

After receiving results of the methodology at the molding stage, we conducted a comparative analysis of the results of the control (CG) and experimental (EG) groups. We found out that control group indicators were not marked by significant changes. 
Fig. 2

Comparative analysis of the results of social competence formation in the control group

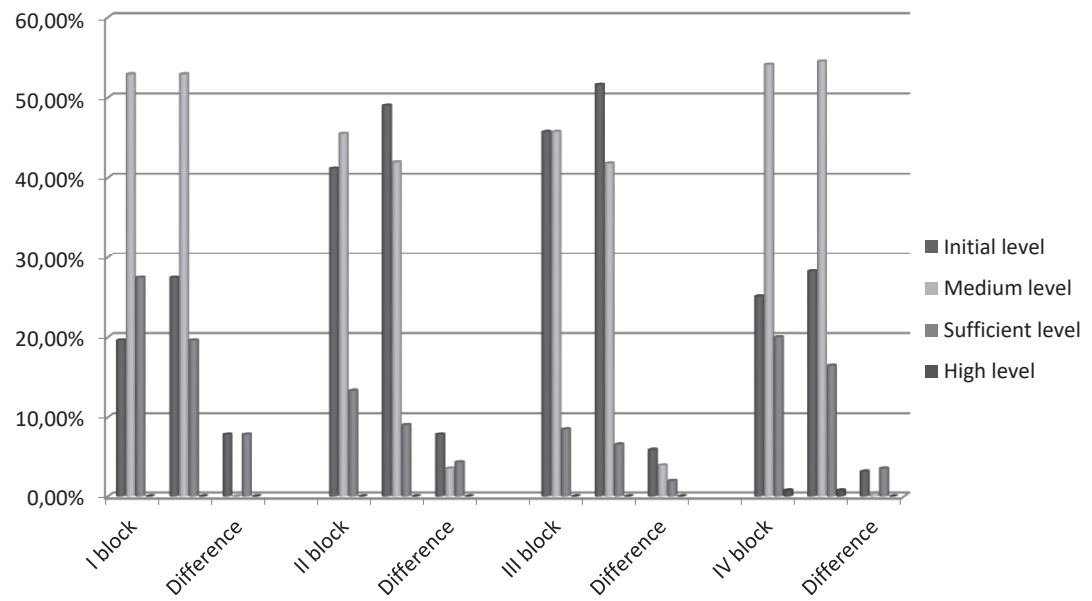

In CG representatives in the first, social-motivational block, we traced an increase of the initial level by $7,84 \%$, the medium level remained unchanged $(52,94 \%)$ - due to the transition of children to another level, sufficient decreased by $7,84 \%$.

In the second, social-cognitive block, the initial level increased by $7,84 \%$, the medium level decreased by 3,53\%, the sufficient level decreased by $4,31 \%$.

In the third, social-activity block, the initial level increased by $5,88 \%$, the medium level decreased by $3,92 \%$, the sufficient level decreased by $1,96 \%$.

In the fourth, social-personality block, the initial level increased by $3,14 \%$, the medium level increased by $0,39 \%$, the sufficient level decreased by $3,53 \%$.

These data indicate ineffectiveness of a standard approach to social competence formation of senior preschoolers with intellectual disabilities.

Representatives of the experimental group (EG) demonstrated positive changes at the molding stage of the study. 
Fig. 3

Comparative analysis of the results of social competence formation in the experimental group

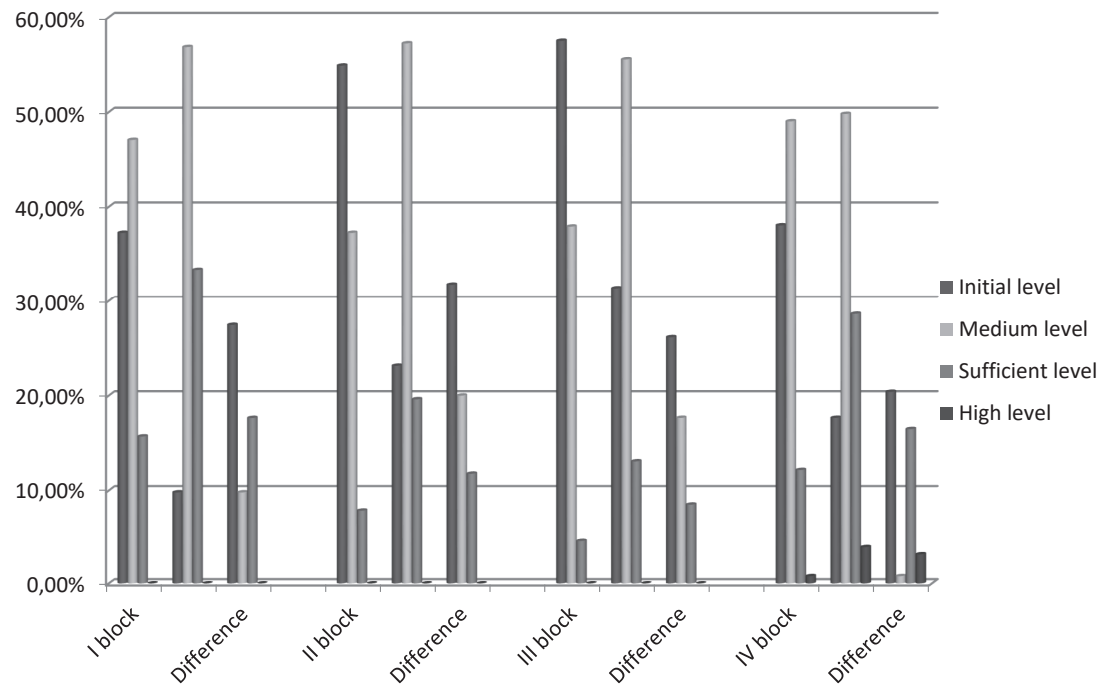

Thus, in the first, social-motivational block of EG, we traced a decrease of the initial level by $27,45 \%$, an increase of the medium level by $9,80 \%$, sufficient- by $17,64 \%$.

In the second, social-cognitive block, the initial level decreased by $31,76 \%$, the medium level increased by $19,99 \%$, the sufficient level increased by $11,77 \%$.

In the third, social-activity block, the following changes occurred: the initial level decreased by $26,15 \%$, the medium level increased by $18,37 \%$, the sufficient level increased by $8,49 \%$.

In the fourth - social-personality block - the initial level decreased by $20,35 \%$, the medium level increased by $0,6 \%$ (remained almost unchanged due to the transition of children to thesufficient and high levels), the sufficient level increased by $16,47 \%$, the high level increased by 3,14\%.

Obtained results indicate effectiveness of the application of this model in practice of institutions of special preschool education. Application of this model in the practice of working with preschool children with intellectual disabilities gives them the opportunity to acquire new links, concepts and knowledge through constant repetition, activity and modelling behaviors in different social situations according to the pattern. 


\section{Conclusions}

Thus, according to obtained results of determining the effectiveness of using the model of social competence formation of preschool children with intellectual disabilities, we have found out that the model we created is effective in working with children of a particular nosology. In our opinion, this model can be the basis for the creation of educational-upbringing and correctional-developmental programs for preschoolers with intellectual disabilities.

\section{References}

Belitskaya, G., E. (2000). Social competence of the individual. Personality consciousness in a crisis society, № 8. 31-36.

Bondar, V., I. (2003). Integration of children with disabilities into general education institutions: pros and cons. Defectology, No. 3. 2-5.

Bozhovych, L., I. (1968). Personality and its formation in childhood (psychological study). Moscow: Enlightenment.

Doktorovych, M., A. (2009). Social competence as a scientific problem. Psychology and society, No. 3. 144-147.

Elkonin, D., B. (2007). Child psychology: textbook for students of higher education institutions. $\left(4^{\text {th }}\right.$ edition). Moscow: Academy.

Gavrilushkina, O., P. (2012). Social competence of normally developing children and their peers with disabilities in today's sociocultural environment. Bulletin of the Teaching-methodological association of Russian universities for psychological and pedagogical education, № 2 (3). 121-132.

Kononko, O. L. (2005). Today's landmark - a competent personality. Preschool education, № 7. 4-5.

Mudryk, A. K. (2008). Social intelligence and social competence. Practical psychology and social work, № 3. 4-6.

Nafikova, L. A. (2004). Formation of the basics of social activity of visually impaired junior pupils in the process of artistic extracurricular activities. Scientific journal of M. P. Dragomanov National Pedagogical University. Series 14 "Theory and Methods of Art Education", Issue 1 (6).

Nikolaieva, O., A. (2014). Formation of social competence in preschoolers with disabilities. Osov Pedagogical Readings "Education in the Modern World: New Time-New Solutions", № 1. 252-258.

Ostrovska, K., O. (2009). Formation of social competences in children with a spectrum of autistic disorders. MP Dragomanov NPU Scientific Journal, Series 19. Correctional Pedagogy and Special Psychology, № 14. 226-232.

Petrovska, L., A. (1989). Competence in communication: social and psychological training. Moscow: Moscow University Publishing House.

Ponimanska, T., I. (2006). Preschool pedagogy. Tutorial. Kyiv: Academvydav.

Pozdniakova, O., L. (2008). Organization of educational work according to the technology of projective life realization. Defectology, № 1. 33-37.

Sinyov, V., M., Matvieieva, M., P., Khokhlina, O. P. (2008). Psychology of a mentally retarded child: a textbook. Kyiv: Knowledge.

Sodomnova, N., B.-Ts. (2013). Features of formation of social competences in preschoolers with disabilities. Theory and practice of social development, № 12. 195-200. 
Telna, O., A. (2008). Social activity of blind students as a socio-psychological problem. Scientific journal of NPU named after MP Dragomanov. Series 19. Correctional Pedagogy and Psychology, Issue 10. 292-297.

Trubaichuk, L., V. (2010). Formation of social competence as a factor of development of children's giftedness. Preschool education, № 6. 45-47.

Vygotsky, L., S. (2004). Child developmental psychology. Moscow: Exmo.

Vysotska, A., M. (2015). Program for development of preschool children with mental retardation "Formation of social skills": method. recommend. Ternopil: Traveler.

Zaporozhets, A., V. (1978). Importance of early childhood for the formation of a child's personality. In Antsyferova, L. (Ed.), The principle of development in psychology (pp. 243-267). Moscow: Science.

\section{Contact:}

Anna Kurienkova

postgraduate student of Chair of Special and Inclusive Education

of Sumy State Pedagogical University named after A. S. Makarenko

e-mail: ann.kurenkova.91@gmail.com

Anna Kurienkova postgraduate student of Chair of Special and Inclusive Education of Sumy State Pedagogical University named after A. S. Makarenko. Circle of scientific interests - formation of social competence of preschool children with intellectual disabilities by role-playing games of social orientation

Yuliia Bondarenko - doctor of Pedagogical Sciences Professor of Chair of Special and Inclusive Education of Sumy State Pedagogical University named after A. S. Makarenko. Member of the creative group of the Typhlopedagogy Laboratory of the Institute of Special Pedagogy of the National Academy of Pedagogical Sciences of Ukraine for the development of software and methodological support. Scientific interests are current problems of education and upbringing of children with special needs in an integrated and inclusive educational environment. 